\title{
PROBLEMATIKA DAŇOVÉ SOUSTAVY Z POHLEDU ZKOUMÁNÍ NÁZORŮ VYBRANÝCH POSLUCHAČŮ VYSOKÝCH ŠKOL EKONOMICKÉHO ZAMĚŘENÍ
}

\author{
Monika Wiesner, Eva Mauritzová
}

Klíčová slova:

daňová soustava, daňový poplatník, daňová politika, daňový systém

\section{Key words:}

tax system, tax payer, tax policy, tax system

\begin{abstract}
Abstrakt
Příspěvek se zaměřuje celkově na daňovou soustavu České republiky s jejím následným vývojem až do současnosti. Rovněž je také zacílen na problematiku a výsledky související s výzkumnou zprávou, a to zejména zhodnocení názorů jednotlivých posluchačů vysokých škol ekonomického zaměření. To znamená jejich rozsáhlejší vnímání problematiky daňové soustavy a daňové politiky na území tohoto státu. Jedná se o posluchače Vysoké školy podnikání v Ostravě a Obchodně podnikatelské fakulty v Karviné (SU v Opavě), kteří jsou občany České republiky a mají praktickou zkušenost s podáváním daňového přiznání. Publikovaná data a jednotlivé výsledky byly získány v období srpna 2011 až ledna 2012. Zkoumané oblasti byly rozděleny do pěti skupin, a to výše sazeb daně; srozumitelnost, aplikace a kvalita daní; rozsah daňové soustavy; vliv daní na podnikání v České republice a účelnost daní. Výsledky výzkumu prokazují dlouhotrvající problémy české daňové soustavy a celkovou nespokojenost daňových poplatníků, i když ze strany vlády dochází k daňovým reformám ve snaze zlepšit celkový stav této problematiky. Tento př́spěvek je současně výstupem z výzkumné zprávy Problematika daňové soustavy z pohledu zkoumání názorů posluchačů vysokých škol ekonomického zaměření.
\end{abstract}

\begin{abstract}
Overall this article is focused on the tax system of the Czech Republic and its subsequent development to the present time. It is also targeted at the issues and results related to the research reports and in particular the evaluation and findings by examination the individual views of economic university students, also their extensive economic perceptions of the tax system and tax policy of this state. In essence, there were chosen some students of University Business in Ostrava and the School of Business Administration in Karviná (SU in Opava), who are citizens of the Czech Republic and have practical experience in the use of tax return. Published data and the individual results were obtained in the period of August 2011 to January 2012. The examined areas were divided into five groups, namely the extent of tax rates; clarity, application and quality of taxes; the range of the tax system; the impact of taxes on business in the Czech Republic and the purposefulness of taxes. The research results confirm prolonged problems of the Czech tax system and the overall dissatisfaction of tax payers, even though the government is willing with an effort to improve this overall state by tax reforms. This article is the output of research reports called Tax system from the examinations point of view, opinions from selected students of economics universities.
\end{abstract}




\section{Úvod}

„Nic není na světě jistého, jen smrt a daně“, tento světově známý citát vyslovil před více než dvěma sty lety vynálezce a politik Benjamin Franklin. Je tomu tak proto, že zdanění, předmět mnoha polemik a politických diskuzí provádí společnost již od nepaměti. Současnou dobu lze charakterizovat jako dobu nezadržitelně postupující globalizaci světa, taktéž jako dobu změny lidského smýšlení a také neodvratitelného technického pokroku, který $\mathrm{k}$ tomu patří (Kubátová, 2000).

\section{Teoretický vstup do zkoumané problematiky}

Obecně daně a daňová soustava prošly dlouhým historickým vývojem a formovaly se už od starověkých civilizací, jako jsou např́iklad Mezopotámie, Egypt, Babylón a Řecko. V období starověké Mezopotámie, to je 4000 př. n. 1. až 6. století př. n. 1. se daně vybíraly pouze v naturáliích. Obvykle společností uznávaným platidlem bylo zejména obilí. Daně měly také formu určité dávky, kterou stanovil panovník, např́íklad povinné odevzdávání vlny. Jediný rozpor nastal v případě stanovení jednotné výše dávky (Oppenheim, 1977). V časech vrcholného období světové velmoci Babylonu byl v čele úspěšný vládce Chamurapi, který prosazoval stř́́brný ekvivalent a panovnickou moc (Boiy, 2004). Od roku 2850 př. n. 1. Egypt'ané zavedli dvouleté zdaňovací období, které trvalo až do roku 2000 př. n. 1., následně nastoupilo každoroční zdaňování. Tehdejší daňovou základnu tvořila pro lepší představu, například daň ze zahrad, z dobytka, z domácích prací, výživa poslů a úředníků na cestách, zdanění chrámů (Kerrigan, 2009). Ve starodávném Řecku měly první daně dokonce plně dobrovolný charakter a jejich placení bylo vyjádřením občanské uvědomělosti. Podpůrnou roli $\mathrm{v}$ rámci př́ijmů rozpočtů hrály daně taktéž $\mathrm{v}$ období raného feudálního státu. Jejich výběr byl vázán především na válečné expanze či případy ohrožení státu jinou mocností. Dělo se tak formou tributů či veřejně organizovaných sbírek (Osborne, 2011).

Co se týče starověkých států a měst, lze sumárně konstatovat, že do té doby neexistoval daňový systém jako takový. Existovala soustava daní vytvářená ad hoc podle okolností. Nebyl uplatňován jednotný př́stup - každý státní útvar si hledal cestu k tomu, jakým způsobem sdělit obyvatelstvu, že mají přispívat na činnost státu. V letech 476 až 1492 tedy v období středověku postupně vznikaly nové druhy daní, které již neměly povahu nahodilého př́ijmu a začínaly mít peněžitý charakter. V souladu s učením o trojím lidu se vytvořila řada výjimek z placení daní, kdy církev a šlechta byly daňově osvobozeny. V této době můžeme zaznamenat existenci čtyř druhů odvodů, a to domén, regálů, kontribucí a akcízů. Domény představovaly odvody $\mathrm{z}$ výnosů panovníkova majetku a měly převážně naturální povahu. Regály zpoplatňovaly propůjčení práv patřící výlučně panovníkovi, zejména právo těžby, vaření piva, regál mincovní, regál horní, regál soudní a další (Spunar, 1995).

\section{Současný stav daňové politiky a daňového systému}

Na přelomu 19. a 20. století došlo k rozsáhlým daňovým reformám. Daňový výnos se již nestanovoval dle vnějších znaků nýbrž podle skutečného stavu. Daň se vybírala na základě daňového přiznání a cla bývala uvalena $v$ převážné míře jen na dovoz. V široké míře byla uplatňována progresivní sazba daně, kterou vyžadoval vznik početného dělnictva. Pro lepší ilustraci je nutno zmínit, že byly zaváděny válečné daně, majetkové daně postihující nejbohatší obyvatele, válečné přirážky $\mathrm{k}$ již povinným daňovým odvodům a intenzivní zdanění vysokých př́ijmů. Teprve v 70. a 80. letech 20. století docházelo ke snižování daňového břemene a mezních sazeb daně. Do popředí se začínaly dostávat neprrímé daně, jejichž podíl na celkových výnosech daně postupně rostl. V tomto období byly započaty první 
pokusy o harmonizaci daní v mezinárodním měřítku. Dělo se tak na půdě Evropského hospodářského společenství, jehož členové postupně zaváděli do svého daňového systému daň z přidané hodnoty (dále DPH). (Široký, 2011). V historickém studiu vybírání daní a jejich metod sběru lze obecně konstatovat, že mají bohatou rozmanitost ve svém vývoji. Tyto metody sběru je možno seskupit podle základu pro platbu mezi vládou a výběrčími. Tři obecné kategorie byly pozorovány, a to: sdílení smluv, s uvedením podílu, z kterého by obě strany sdílely daňové př́ijmy. Nájemné smlouvy, kde by výběrčí platil vládě pevnou částku založenou na hodnotě základu daně, a mzdové smlouvy, specifikující pevnou mzdu a vládě by platil výběrčí za jeho práci (Cosgel and Miceli, 2007). V současné době lze zaznamenat pokračování trendu zvyšování podílu nepřímých daní stejně jako rozsáhlou harmonizaci v oblasti daně z přidané hodnoty na území členských států Evropské unie. Jednotlivé státy taktéž velmi intenzivně spolupracují v oblasti zamezení dvojího zdanění, poskytování vzájemných daňových informací a v oblasti boje proti daňovým rájům.

Je nutno zdůraznit, že daňová teorie a politika je jednou z hlavních a rozhodujících oblastí státní rozpočtové politiky. Daň tedy představuje nejdůležitější část rozpočtových př́imů. Podle autorky Kubátové, K. je možno daň definovat jako „povinnou, nenávratnou, zákonem určenou platbu do veřejného rozpočtu. Je to platba neúčelová a neekvivalentní.“ (Kubátová, 2000). Určitým charakteristickým rysem daní může být i jejich pravidelnost např́iklad každoročního placení daní z prríjmů, ale i jejich nepravidelnost naprríklad při převodu nemovitostí (Vančurová, Láchová, 2010). Taktéž je potřebné zmínit, jaké funkce mají obecně daně, protože jejich vliv na ekonomickou realitu je nesporný. Mezi hlavní funkce daní se nejčastěji řadí: alokační, redistribuční a stabilizační. Co se týče první zmíněné funkce, uplatňuje se $\mathrm{v}$ př́padech, když tržní mechanismy nemohou zajistit efektivnost $\mathrm{v}$ alokaci zdrojů. Zejména $\mathrm{v}$ situacích nedokonalé konkurence, kde daně mohou tuto nedokonalost korigovat a zabezpečit, aby finální lokace prostředků byla přesně tam, kde by se jí při tržní alokaci nedostávalo. Následně redistribuční funkce vychází ze situace, že obecné mínění pro rozdělení důchodů a bohatství ve společnosti vlivem fungováním trhu je neakceptovatelné. $\mathrm{Z}$ tohoto důvodu daně zmírňují rozdíly $\mathrm{v}$ důchodech jednotlivých subjektů takovým způsobem, že část důchodu a bohatství se přesouvá směrem od bohatších jedinců k chudším. Poslední zmiňovaná stabilizační funkce zmírn̆uje naopak cyklické výkyvy v ekonomice, a to v zájmu zajištění cenové stability a dostatečné zaměstnanosti. Někdy bývá proto označována jako ekonomická funkce, protože souvisí s hospodářskou politikou státu, je tedy její součástí (Kubíček a kol., 2006).

Základní součástí fiskální, tedy i celkové hospodářské politiky státu, je daňová politika. Představuje silný nástroj vlády, který je zejména používán k ovlivňování ekonomického růstu. Je možno ji charakterizovat také jako hlavní zdroj při přerozdělování důchodů. S výše uvedeným velmi úzce souvisí daňový systém jako takový. Lze pod ním chápat nejen daňovou soustavu, ale celý systém právních, organizačně-technických a kontrolní institucí, které zajišt'ují tvorbu legislativy, správu daní, kontrolu a vymáhání. Jedná se o systém nástrojů a metod, které instituce využívají ve vztahu $\mathrm{k}$ daňovým subjektům. Daňová soustava představuje souhrn všech daní, které se na daném území vybírají (Vítek, 2001). Aktuální přehled daňové soustavy v České republice je názorně zobrazen v níže uvedeném v Obrázku 1: Daňová soustava ČR. 
Obrázek 1: Daňová soustava ČR

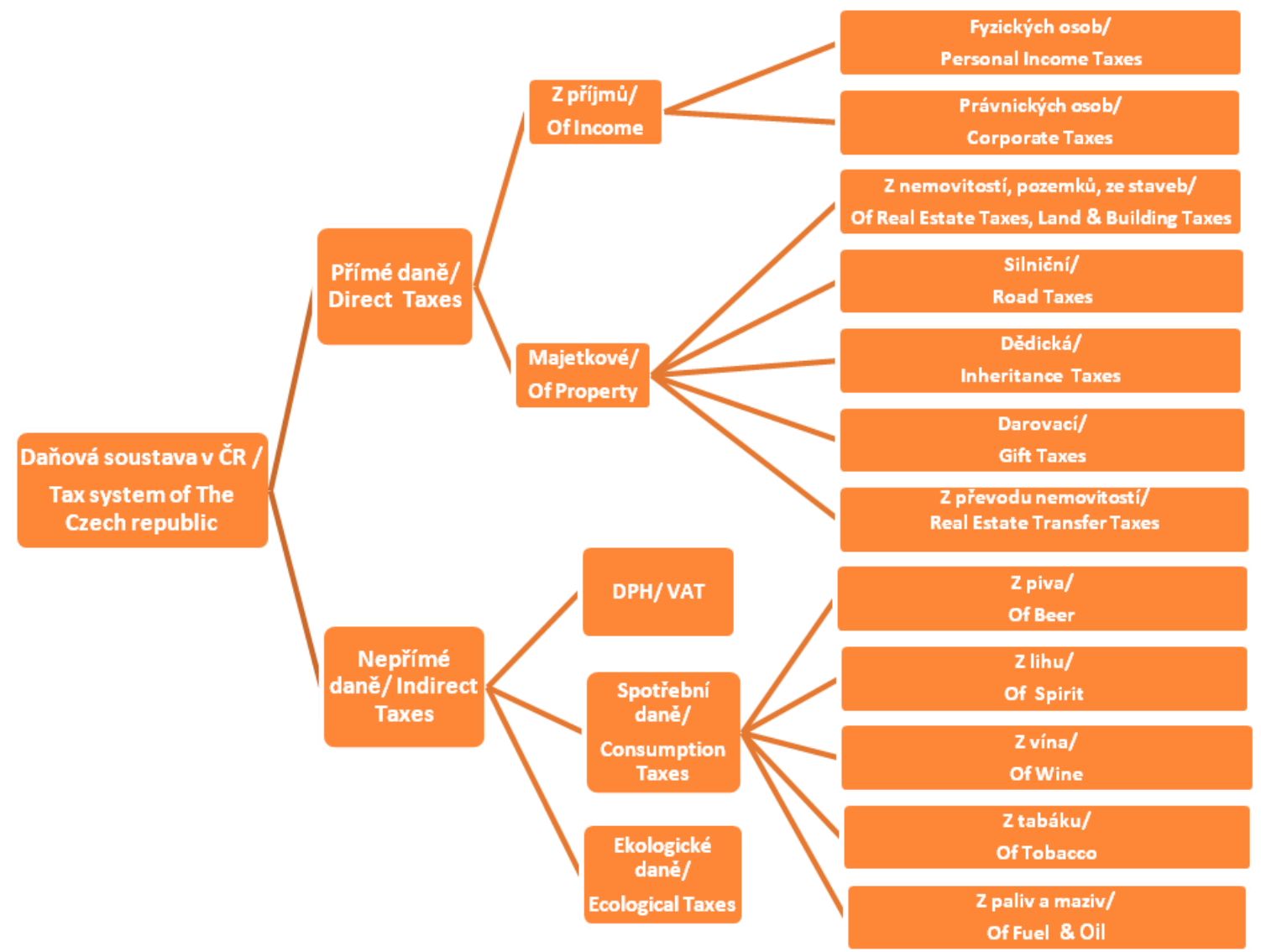

Pramen: Daňová soustava ČR. Vlastní zpracování autorek, 2012. Dostupné na WWW: <http://www.mfcr.cz/>. [online], [cit. 2012-02-01]; MARKOVÁ, H. 2012.

Současná daňová soustava resp. její členění vychází od roku 1993, tedy od vzniku samotné České republiky. Ve své podstatě je založena na zdanění oblastí př́ijmů, konkrétně se jedná o daň z př́ijmů právnických osob a fyzických osob (viz Zákon č. 586/1992 Sb., o daních z př́ijmů ve znění pozdějších předpisů). Další zdaňovanou oblastí je zdanění spotřeby, a to daň z přidané hodnoty (viz Zákon č. 235/2004 Sb., o dani z přidané hodnoty), následně se jedná o příspěvky sociálního pojištění (viz Zákon č. 100/1988 Sb., o sociálním zabezpečení ve znění pozdějších předpisů a Zákon č. 582/1991 Sb., o organizaci a provádění sociálního zabezpečení, ve znění pozdějších předpisů). Doplňujícími elementy daňové soustavy jsou majetkové daně (viz Zákon č. 16/1993 Sb., o dani silniční, také Zákon č. 357/1992 Sb., o dani dědické, dani darovací a dani z převodu nemovitostí ve znění pozdějších předpisů), zvláštní poplatky, a to zejména místní a cla (viz Zákon č. 13/1993 Sb., celní zákon ve znění pozdějších předpisů).

Je potřebné si uvědomit, že každá země si vytváří daňovou soustavu z více daní. Každá daň má své kladné a záporné stránky a tím, že se vytváří určitý systém daní, jejich negativní dopady se částečně vyruší a lépe plní své funkce v rámci své fiskální politiky. Daně představují výsledek složitého prolínání zájmů různých skupin, a v určitém období je jejich podoba výsledkem rozložení politických stran. Okrajově je důležité také vzpomenout, že v podmínkách fungování tržní ekonomiky je daňová soustava založena na určitých daňových principech, mezi které řadíme zejména: princip daňové spravedlnosti, princip daňové efektivnosti, princip právní perfektnosti, princip jednoduchosti a srozumitelnosti, princip správného ovlivňování chování ekonomických subjektů, princip neutrality a princip daňové univerzality. Všechna pravidla související se stanovením a výběrem daní musí být přesně 
formulována prostřednictvím legislativní normy. Vývoj daní prošel dlouhou genezí. Dá se říci, že daně mají stejně dlouhou historii jako stát. Každý stát musel i v minulosti hradit určité potřeby související např́iklad s provozem panovníkova sídla, nebo obrany státu. Daně měly na počátku svého vzniku většinou naturální podobu, ale jak už bylo zmíněno na začátku této kapitoly, postupně procházely do podoby peněžní. Daň v dnešním pojetí se prostřednictvím peněžního plnění odlišuje od svých předchůdkyň (Janoušková, 2011). V následujícím Grafu 1: Podíl vybíraných daní na daňových př́imech v letech 2009 a 2010 v České republice je názorně ilustrována komparace těchto dvou let.

Graf 1: Podíl vybíraných daní na daňových př́ijmech v letech 2009 a 2010 v České republice

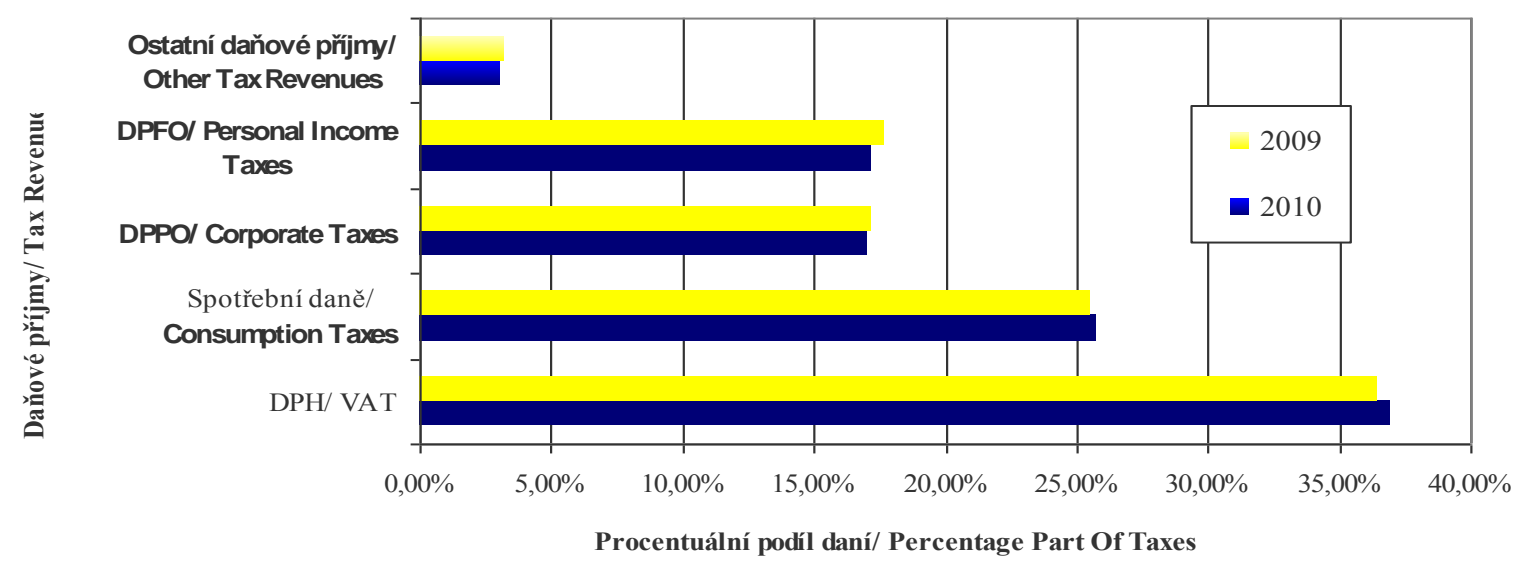

Pramen: Podíl vybíraných daní na daňových př́imech v letech 2009 a 2010 v České republice. Vlastní zpracování autorek na základě dat získaných z WWW:

<http://www.mfcr.cz/cps/rde/xchg/mfcr/xsl/statni_zav_ucet_62819.html?year=PRESENT>. [online]. [cit. 2012$02-02]$.

Jak je patrno z výše uvedeného Grafu 1, inkaso neprímých daní bylo v roce 2010 vyšší než $\mathrm{v}$ roce 2009. Důvodem nárůstu v roce 2010 byla řada legislativních změn, které znamenaly změny $\mathrm{v}$ daňové oblasti. Týkaly se př́mo DPH, kdy základní sazba byla zvýšena o jeden procentní bod tedy na $20 \%$ a snížená sazba byla zvýšena také o jeden procentní bod a činila $10 \%$. Také v tomto uvedeném roce došlo ke změnám u spotřebních daní, tedy u sazeb daně z minerálních olejů, spotrební daně z lihu, z piva a tabákových výrobků. ${ }^{1}$ Uvedené změny měly za následek zvýšení nepř́mých daní v roce 2010. Toto zvýšení je plně v souladu se záměry daňové politiky Evropské unie a $\mathrm{v}$ ohledu snižování daňového břemena daní př́imých na úkor daní nepř́mých. Členské státy Evropské unie si stanoví sazby daně ze zisku společností, z prŕijmu fyzických osob, z úroků z vkladových účtů či kapitálových výnosů. Je nutno zdůraznit, že Evropská unie tato rozhodnutí pouze sleduje a posuzuje, zda jsou spravedlivá vůči Evropské unii jako celku. Jedná se o to, že daňové předpisy členských států musejí být $\mathrm{v}$ souladu s cíli EU v oblasti zaměstnanosti, nesmějí bránit volnému pohybu zboží, služeb a kapitálu v EU a nesmějí ani poskytovat nespravedlivou výhodu podnikům z jednoho státu vůči konkurenci z ostatních zemí. Mimo jiné si členské státy udržují kontrolu nad zvyšováním

\footnotetext{
${ }^{1} \mathrm{~V}$ př́ípadě sazeb spotřební daně u pohonných hmot se jednalo o zvýšení sazby přibližně o 1 Kč/l, u spotřební daně z lihu se zvýšila sazba, která měla ve svém důsledku vést $\mathrm{k}$ nárůstu ceny 0,5 litru 40 \% lihoviny o přibližně 5 Kč včetně DPH. Sazby této daně jsou stanoveny v Kč/hl etanolu. U piva došlo ke zvýšení daně o 8 Kč/hl na každé procento extraktu původní mladiny, což činilo přibližně 0,50 Kč na půllitr 100 piva. Ke změně sazeb tabákových výrobků došlo od 1. února 2010, a to v př́padě cigaret došlo ke zvýšení pevné části daně o $0,04 \mathrm{Kč} / \mathrm{kus}$, u tabáku ke kouření a ostatního tabáku o $60 \mathrm{Kč} / \mathrm{kg}$. Další sazby byly uvedeny v $\S 48$ zákona č. 353/2003 Sb., o spotřebních daních.
} 
daní, protože podle právních předpisů Evropské unie musí každé rozhodnutí Unie v daňové oblasti jednomyslně odsouhlasit všechny členské státy.

\section{Materiál a metodika}

Hlavním cílem př́íspěvku je popsat celkově daňovou soustavu České republiky s jejím následným vývojem až do současnosti. Dále na základě výzkumné studie zhodnotit a zjistit prostřednictvím zkoumání názorů vybraných posluchačů, vysokých škol ekonomického zaměření, jejich rozsáhlejší vnímání problematiky daňové soustavy a daňové politiky na ČR. Konkrétně se jednalo př́mo o posluchače Vysoké školy podnikání v Ostravě a Obchodně podnikatelské fakulty v Karviné (SU v Opavě). Objektem výzkumu byli poplatníci daně z př́ijmů fyzických osob, studenti, kteří jsou občany České republiky. Všichni vybraní respondenti mají praktickou zkušenost s podáváním daňového přiznání. Studenti jsou zároveň posluchači čtvrtého ročníku jednou ze dvou vybraných vysokých škol. Od výše uvedeného hlavního cíle se odvíjejí následně cíle dílčí, a to zhodnocení celkového vnímání daňové zátěže, a také posouzení aktuálního stavu daňové politiky České republiky a definování konkrétních východisek pro aplikaci možných směrů vývoje v budoucím období. Na základě informací a názorů získaných z celkového počtu 200 dotazníků (pozn. 100 respondentů z OPF a 100 respondentů z VŠP) je možno rozdělit výsledky do pěti skupin, a to konkrétně: 1) Výše sazeb daně; 2) Srozumitelnost, aplikace a kvalita daní; 3) Rozsah daňové soustavy; 4) Vliv daní na podnikání v České republice; 5) Účelnost daní. Samotná realizace výzkumu tzn. sběr dat a následně i zpracovávání je náročný proces, a proto byly aplikovány obecně vědní metody. Pro potřeby tohoto př́spěvku a pro řešení hlavního cíle je použita pozitivistická metodologie. $Z$ tohoto titulu jsou aplikovány pozitivistické metody, především analýza a komparace ad. Zajisté $\mathrm{v}$ práci jsou využity také metody normativní v oblasti možných legislativních úprav.

Analýza je metoda rozborová, která znamená postup od celku k jednotlivým částem. V tomto př́spěvku byla použita analýza při vyhodnocování získaných dat u aktuálního stavu daňové politiky České republiky. Taktéž je použita při definování, charakterizování a klasifikaci základních pojmů, obecných vlastností daňových systémů, vzájemných vazeb a jejich působení atd. Dále byla použita metoda syntézy. Tato metoda se využila při zhodnocení získané poznatky a formulovat návrhy, doporučení. Komparace je základní porovnávací metodou. Při její aplikaci dochází k hodnocení na základě porovnání dvou stavů, např. stavu žádoucího a stavu skutečného. Z porovnávání těchto dvou jevů pak může vyplynout odchylka kladná, záporná anebo nulová. $\mathrm{V}$ př́śspěvku je využita i metoda komparace pro porovnání vyjádřených názorů posluchačů vysokých škol ekonomického zaměření ohledně daňového systému v České republice. Metoda dedukce je aplikována v průběhu celé tvorby výzkumné zprávy i př́spěvku, zejména však při realizaci a vyhodnocování výzkumného šetření a celkových výstupů zejména po analýze, jsou odvozeny určité soudy. Abstrakce se používá téměř vždy a umožňuje odhlížet z celistvé reality některou její část, např. vlastnosti. $V$ tomto př́spěvku je tato metoda aplikována $\mathrm{v}$ souvislosti s konkrétním dopadem daňové politiky na zaměstnance, kde nebude brán zřetel na vliv všech politik ČR. Použité data a podklady v rámci tohoto příspěvku jsou součástí výzkumné zprávy Problematika daňové soustavy $\mathrm{z}$ pohledu zkoumání názorů posluchačů vysokých škol ekonomického zaměření.

\section{Výsledky a diskuse}

$\mathrm{Na}$ základě dotazníkového výzkumu byl sestaven celkový přehled jednotlivých názorů respondentů-daňových poplatníků. $\mathrm{V}$ předmětně oblasti výzkumné činnosti je tato činnost 
specificky zaměřena na obecné i odborné otázky vybraných kategorií. Tj. vlastní vnímání daní, způsoby plnění daňových povinností a kvalitu systému správy. Následně pak praktickou aplikaci daňové soustavy, daňové politiky a daňového systému v kontextu s jejich vlastní výdělečnou činnosti.

Výše sazeb daně: celkový počet 100 respondentů z OPF a taktéž 100 respondentů z VŠP byli dotazováni, jaký názor zastávají $\mathrm{v}$ této oblasti zejména pro daň z př́jmů fyzických osob. Z výzkumu vyplývá, že $\mathrm{v}$ této zkoumané oblasti Výše sazeb daně se názory respondentů výrazně nerozcházely. Zajímavé je uvedení ,„príliš nízké“ zdanění jako názoru u OPF, kdežto u respondentů VŠP takových názor nezastával ani jeden student. Celkově je možno konstatovat, že shoda u obou vysokých škol panovala u odpovědi „př́lišs vysoké“ a „spíše vysoké“", což je možno považovat za signál, že daňoví poplatníci jsou silně zatížení z daňového pohledu. Nižší daně rozšiřují prostor pro individuální iniciativu a svobodu jednotlivce a také přispívají k růstu ekonomiky, stát více vybere na daních. Taktéž přispívají do státního rozpočtu podstatně větším daňovým výnosem, jelikož jsou placeny ve větším objemu, to znamená $\mathrm{z}$ většího daňového základu. $\mathrm{Z}$ dlouhodobého hlediska by to mohlo vést $\mathrm{k}$ nahrazování práce volným časem, to znamená ke ztrátě motivace k práci, jak uvádí ve své teorii Lafferova křivka.

Další zkoumanou oblastí bylo vyjádření se k představě, jaké adekvátní zdanění u fyzických osob by mělo být zavedeno na území ČR, jak zejména ilustruje Graf 2: Představa vybraných respondentů o adekvátním zdanění $\mathrm{v}$ České republice. Kde na ose $\mathrm{x}$ jsou vyjádřeny počty studentů a na ose y jsou uvedeny navrhované intervalové sazby ohledně adekvátní daňové sazby pro daň z př́ijmů fyzických osob.

Graf 2: Představa vybraných respondentů o adekvátním zdanění v České republice

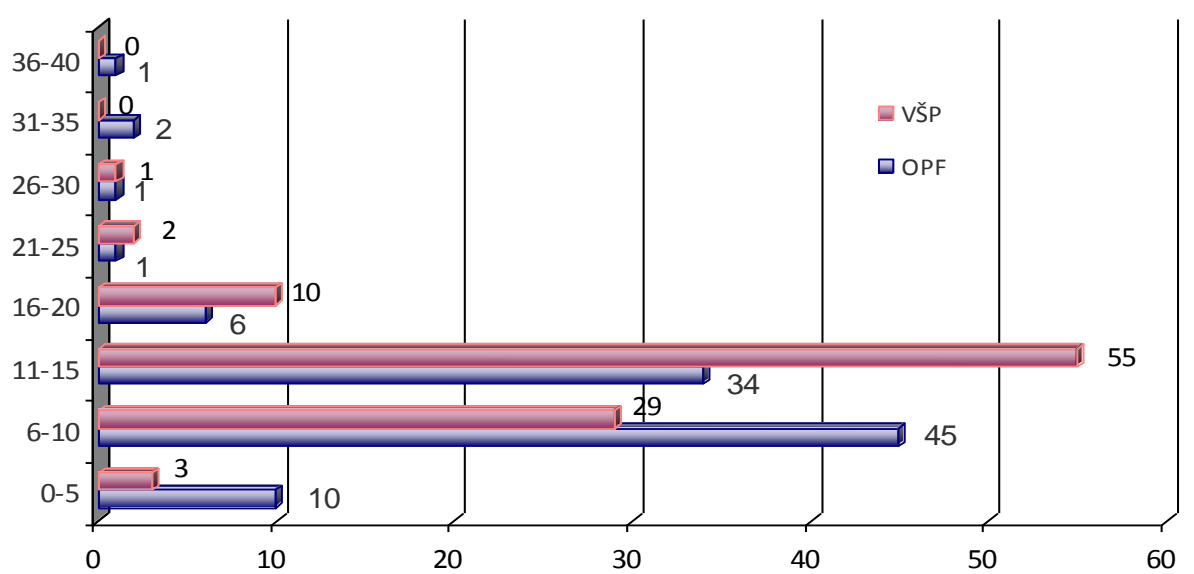

Pramen: Vlastní výzkum autorky (Wiesner, M.), 2011-2012.

Z výše uvedeného Grafu 2 Představa vybraných respondentů o adekvátním zdanění v České republice jsou patrné názorové rozptyly obzvláště u OPF, kde se objevily i procentuální sazby 0; 3 a 4, což signalizuje pocit vysokého daňového zatížení v ČR. Velmi zajímavý se jeví názor, že daňové zatížení je naopak nízké, jak dokládají navrhované sazby 35 a $40 \%$, jako důvod bylo uvedeno, že státy sociálního blahobytu - tedy státy Skandinávské mají taktéž vysoké zatížení a jejich ekonomická úroveň se i nadále drží na vrchních pozicích Evropské unie i v období recese. Co se týče samotné četnosti odpovědí, celkem 29 studentů OPF uvedlo přímo adekvátní $10 \%$ sazbu. VŠP měla nejvyšší četnost konkrétně u navrhované sazby $15 \%$ 
a to se 21 odpověd'mi, z čehož je možno usoudit, že studenti VŠP považují aktuální vládou schválenou sazbu za adekvátní k životní situaci v České republice.

Srozumitelnost, aplikace a kvalita daní: oblast srozumitelnosti je považována za velmi důležitou, je to odrazem toho, jak je vnímána daňová soustava daňovými poplatníky a dalšími subjekty v ekonomické realitě. Jelikož správné chápání zaručuje dobrou vymahatelnost daní, celkovou správu a taktéž podporuje princip daňové spravovatelnosti. Obecně je možno konstatovat, že dobrá srozumitelnost tímto zajistí daňovou spravedlnost pro každého daňového poplatníka, a taktéž dochází k menšímu počtu chyb a dalším problémům způsobeným nesrozumitelností daňové soustavy. Co se týče srozumitelnosti daní je možno vyvodit dílčí závěr, že pro daňové poplatníky je česká daňová soustava jen částečně srozumitelná. To znamená, že pro studenty OPF je částečně srozumitelná celkem na $64 \%$ a pro studenty VŠP srozumitelná na $42 \%$. Aplikace daňových zákonů v praktickém životě na území tohoto státu je jedním z hlavních determinantů úspěšného výběru daní a zamezení daňových úniků. Česká republika bývá kritizována za složitost daňových zákonů a velkou administrativní náročnost. Z tohoto důvodu bylo na místě zhodnotit tuto kritickou poznámku z pohledu samotných daňových poplatníků. Z praktického pohledu jednotlivých daňových poplatníků-studentů OPF je možno vyvodit závěr, že celou aplikaci daňových zákonů v praxi nepovažují za dobře řešenou, a proto je i výběr daní neefektivní. Také se objevila konstruktivní kritika ohledně každoročního sestavování daňového přiznání, které je značně komplikované, plné výjimek a odkazů na další zákony. Kdežto respondenti z VŠP naopak jsou spíše spokojeni s celou aplikací daňových zákonů na území České republiky. Pravděpodobným důvodem tohoto dílčího výsledku je jejich hlubší pohled do této problematiky z praktické roviny.

S praktickou rovinou souvisí i další zkoumaná oblast, a to celková kvalita správy daní, respektive finančních úřadů. Dotaz ohledně této problematiky byl zacílen na celkovou kvalitu a hladkost vyřízení vzniklých problémů. Obecně je možno konstatovat, že finnanční úřady bývají kritizovány za zdlouhavá a mnohdy neochotná jednání ze strany úředníků. Je nutno zdůraznit, že právě úřredníci na jednotlivých finančních úr̆adech zastupují stát ve věcech veřejných. Taktéž daňoví poplatníci jsou zatíženi nepřehledností daňových zákonů, jejich neustálých novelizací a $\mathrm{z}$ toho vyplývající obavy ze sankcionování ze strany správců daně. V této zkoumané oblasti je možno tvrdit, že daňoví poplatníci na obou vybraných vysokých školách, respondenti dosáhli shody a shledali českou správu daní za spíše kvalitní i přes zaznamenanou kritiku. Důvodem je možná snaha o celkové zlepšení v této oblasti, kde ze strany vlády je vidět tendence a směr ke zlepšení v celkové spolupráci, a to v rámci aktivního př́stupu daňové správy $\mathrm{k}$ veřejnosti.

Rozsah daňové soustavy: to je rozsah vybíraných daní a poplatků, který byl konkrétně zacílen na zjištění, zda je adekvátní $\mathrm{k}$ celkové životní úrovni na území České republiky. Z dotazníkového šetření vyplývá, že daňoví poplatníci OPF zhodnotili daňovou soustavu a to $\mathrm{v}$ ne zcela adekvátním rozsahu vzhledem k celkové životní úrovni. To znamená, že ekonomická realita, se kterou se běžně setkávají, neodpovídá úrovni vybraným daním. Důvodem je již dř́ve uvedený pocit z vysokého zatížení. Tedy ze všech vybraných finančních prostředků necítí užitek vracený státem do ekonomické reality. Kdežto daňoví poplatníci, respondenti z VŠP tento rozsah daňové soustavy vnímají o něco pozitivněji, jejich hodnocení ulpělo nejvíce na úrovni „spíše adekvátní rozsah“.

Vliv daní na podnikání v České republice: daně jsou významným faktorem samotného vzniku a rozvoje podniků, taktéž mají signifikantní vliv na podnikatele. V př́padě vysokého 
daňového zatížení působí spíše tlumícím způsobem a současně výrazně odrazuje od podnikání. Tato oblast byla zkoumána daňovými poplatníky, respondenty na obou vysokých školách, jak prezentuje výsledky Graf 3: Vyšší daně snižují motivaci k podnikání v České republice. Na vybraných vysokých školách ekonomického zaměření, konkrétně OPF a VŠP je možno konstatovat konsensus $\mathrm{v}$ této zkoumané problematice. A to, že daně mají částečný vliv na podnikání v České republice. Jedná se o možnost ovlivnění daňového základu, bud' skutečnými výdaji, nebo paušálními (v případě osob samostatně výdělečně činných). Kdežto zaměstnanecký poměr tuto možnost nenabízí. Relevantním názorem je, že je nutno více podpořit české podnikání, než zahraniční podniky, kde zahraniční firma využívá daňové úlevy a po skončení daňových úlev se přemístí do jiné země, která je z daňového hlediska pro firmu opět daňově výhodná (daňovým rájem).

Graf 3: Vyšší daně snižují motivaci k podnikání v České republice

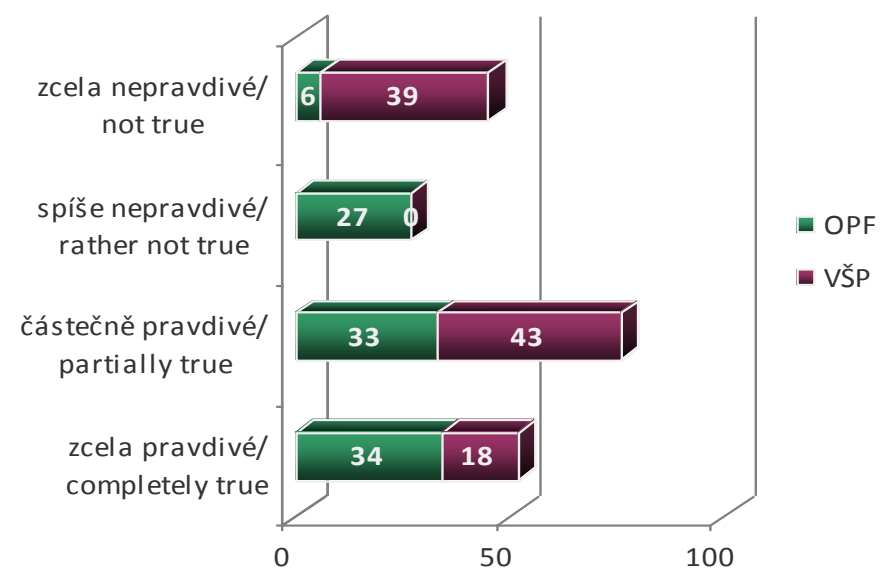

Pramen: Vlastní výzkum autorky (Wiesner, M.), 2011-2012.

Obecně společnost může být daněmi ovlivněna bud' v pasivní, nebo aktivní podobě. Přičemž v pasivní podobě je podnik nucen strpět určité negativní daňové důsledky nebo naopak může pozitivní daňové důsledky využít. $\mathrm{V}$ aktivní podobě podnik využije daně jako možnost se rozhodnout o určité variantě $s$ cílem zvyšovat tržní hodnotu firmy či naplňovat další podnikové cíle. Klíčovou roli hrají daně z př́ijmů, které ovlivňují zejména rozhodování o volbě př́slušné právní formy podnikání, investiční rozhodování, riziko podnikání a způsoby financování podniku. Významnou roli hrají také vzájemné interakce státu a podnikové sféry, zejména pokud se týká daňově uznatelných nákladů, odpočitatelných položek či slev na dani.

Účelnost daní: výběr daní na území České republiky je často kritizován za svou velkou nákladovost $\mathrm{v}$ komparaci $\mathrm{s}$ ostatními zeměmi. Tuto statistiku sestavuje OECD jako sérii srovnávacích informací, jejichž cílem je poskytnout informace o daňových systémech a jejich správě $\mathrm{v}$ členských zemích OECD. Dalo by se říci, že když stojí výběr nemalé finanční prostředky, měly by být $\mathrm{v}$ tomto př́padě využity účelně. Graf 4: Účelnost daní kompletně zobrazuje výsledky z dotazníkového šetření, co týče této účelnosti z pohledu respondentů. 
Graf 4: Účelnost daní

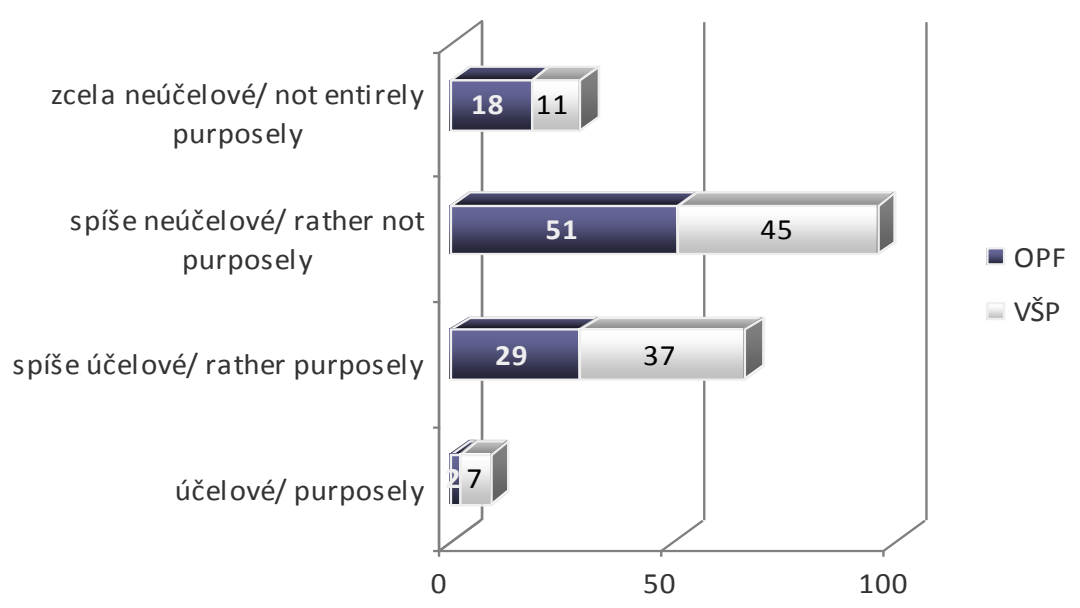

Pramen: Vlastní výzkum autorky (Wiesner, M.), 2011-2012.

Vybraní respondenti na obou vysokých školách vnímají nakládání s vybranými daněmi spíše neúčelně. Vyjádřili tímto již zmíněnou nespokojenost, kdy stát daně sice vybere, ale daňoví poplatníci efektivnost zpětně nepocit'ují. Výše daní je omluvitelná, pokud se s nimi zachází efektivně a mají pozitivní dopad na kvalitu života daňových poplatníků. Podle většiny názorů respondentů je přerozdělování $\mathrm{v}$ České republice neefektivní, necílené a podléhá nesrozumitelně četným výjimkám. Zvyšovaní daní by mohlo být považováno za účelné, tehdy pokud by se zároveň snižovaly i výdaje vlády. Již zmíněné zvyšování daní by mělo být limitováno legislativně a $\mathrm{z}$ důvodu hrozby deformace ekonomiky státu, kdy dochází $\mathrm{k}$ výraznému šetření daňových poplatníků, což následně vede $\mathrm{k}$ nižším nákupům a také k nižší spotřebě. Ve své podstatě se názory posluchačů OPF a VŠP diametrálně neliší.

Hlavním cílem bylo stanoveno zjištění prostřednictvím zkoumání názorů jednotlivých posluchačů vysokých škol ekonomického zaměření rozsáhlejší vnímání problematiky daňové soustavy a daňové politiky v rámci České republiky. Na základě zkoumaných skutečností lze konstatovat, že hlavní i dílčí cíle tohoto výzkumu byly naplněny. Konkrétně se jednalo o zhodnocení celkového vnímání daňové zátěže a posouzení aktuálního stavu daňové politiky České republiky, definování konkrétních východisek pro aplikaci možných směrů vývoje v budoucím období.

Teoretickým prrínosem je sumarizace teoretických přístupů a shrnutí a zhodnocení vývoje českého daňového systému s důrazem na důchodové daně, které tvoří stěžejní pilír každého moderního daňového systému a přestavují podstatný výnos veřejných rozpočtů. Praktickým př́nosem jsou výsledky analýzy, komparace a nalezení souvislostí mezi zkoumanými oblastmi v daňovém systému České republiky. Tyto zkoumané oblasti byly rozděleny do pěti skupin, a to výše sazeb daně; srozumitelnost, aplikace a kvalita daní; rozsah daňové soustavy; vliv daní na podnikání v České republice a účelnost daní. Následně je spatřován př́nos i ve vyhodnoceních dané problematiky a doporučení zejména pro legislativní úpravy, které by vedly $\mathrm{k}$ minimalizaci mezer $\mathrm{v}$ legislativě, ale hlavně ke zjednodušení administrativní náročnosti, která je stále vysoká v komparaci s ostatními zeměmi Evropské unie. Dalším př́nosem je realizace námětů a návrhů opatření jednak ve vztahu ke zkvalitnění klientského (partnerského) přístupu správce daně (využití pro orgány České daňové správy) a dále taktéž i $\mathrm{k}$ případným úpravám i daňové politiky. $\mathrm{K}$ tomu se váže zhodnocení pohledu daňových reforem na území tohoto státu, které neřeší skutečnost, že stát neumí skrze vynutitelnou státní moc říct o to co, mu náleží. Žádná reforma stát neposune, tak jako schopnost efektivně 
postihovat jedince obcházející systém. Výše uvedené není stěžejním problémem daňové politiky, ale legislativy a její striktní prosazování, dodržování a prŕípadné nekompromisní trestání. Jinak zákonitě vše vede ke ztrátám na daňových výnosech státu. Během krátkého období bylo zavedeno př́liš mnoho změn v oblasti daní a daňové politiky a daňoví poplatníci se nestíhají adaptovat novým podmínkám ve stávající daňové politice. Dalším legislativním praktickým přínosem je podnět $\mathrm{k}$ využití odbornosti renomovaných ekonomů pro stanovení výše zdanění, výběru i přerozdělování daní. Praktický př́nos článku je možno spatřovat i v kvalitnější informovanosti veřejnosti, také zpřistupnění relevantních informací laické veřejnosti. Tímto by došlo ke zjednodušení daňového systému, který je kritizován za svou nepřehlednost, složitost a administrativní náročnost $\mathrm{v}$ podobě mnohočetností formulářů. Řešením by mohlo být vytvoření jednoduchých manuálů-příruček při vyplňování daňových přiznání. Zjednodušením by mohlo být i sloučení určitých daní a poplatků s jinými, tímto krokem by se mohly vybírat zároveň. Výběr daní a poplatků by se mohl transformovat výhradně do elektronické podoby - komunikace s úřady a správci daní např́iklad přes datové schránky České pošty, a.s. Výše zmíněné elektronické formuláře by musely mít velmi kvalitní technické zázemí a podporu, aby nedocházelo k problémům během odesílání. Taktéž dalším praktickým přínosem je kontrola povědomí daňové problematiky u dotazovaných studentů. To znamená, jak vnímají samotné daně, způsoby plnění daňových povinností a kvalitu systému správy.

\section{Závěr}

Celá tato problematika je velmi signifikantní, jelikož prostřednictvím daní jsou financovány veřejné statky, které slouží k zajištění ekonomického růstu a životní úrovně obyvatel. Na druhé straně představují daně pro domácnosti i podnikatele značkou újmu, která souvisí jak s př́mou platbou daní, tak $\mathrm{s}$ dalšími náklady vyvolané daňovým systémem, které musí poplatníci ve spojitosti s plněním svých daňových povinností vynakládat. Veškerá pravidla a souvislosti musí být přesně formulovány legislativní formou. Také jednotlivé daňové reformy by měly být zaváděny postupně a $\mathrm{s}$ ohledem na daňové poplatníky, aby nedocházelo $\mathrm{k}$ nepochopení při komplikovanosti samotného výběru daní. Hlavním problémem daňového systému není ani tak jeho samotná složitost, jako spíše vnímání této složitosti mezi veřejností. Systém daní je jedním $\mathrm{z}$ důležitých kritérií $\mathrm{v}$ rámci rozhodování o umístění zahraničních investic. Přilákat do země značné investice může být velice strategický krok a $\mathrm{v}$ době propojenosti trhů panuje mezi jednotlivými státy silná konkurence. Chtějí-li země přilákat nové investory a zvýšit tím i počet nových pracovních míst na svém trhu, musí vycházet podnikatelům vstříc a snažit se jim nabídnout co nejpřijatelnější podmínky. Srozumitelný a především efektivní daňový systém zvyšuje důvěru a ochotu firem v dané zemi investovat. Srovnání času nutného na splnění všech daňových povinností podniků působících v ČR ukazuje, že právě administrativní náročnost daňového systému je jednou z největších slabin podnikatelského prostředí. Obecně vyjádřeno daňová reforma, která začne platit na začátku dalšího roku, bohužel tuto administrativní náročnost nesníží. Problém administrativní náročnosti by měl být $\mathrm{i}$ nadále $\mathrm{v}$ popředí úvah při dalších př́ípadných změnách daňového systému ČR. Proto z pohledu konstrukce daní je třeba definovat základní prvky tak, aby bylo možno vybírat daně v potřebné výši.

Z výsledků dotazníkového šetření studentů vysokých škol vyplývá závěr, že daňoví poplatníci jsou silně zatížení z daňového pohledu. Nižší daně rozšiřují prostor pro individuální iniciativu a svobodu jednotlivce a také přispívají $\mathrm{k}$ růstu ekonomiky, stát má vyšší př́ijem z daní. $\mathrm{Z}$ dalšího bodu šetření je patrné, že pro daňového poplatníka je jednou z priorit, aby placení daní bylo administrativně a nákladově co nejméně náročné, dostatečně srozumitelné a 
současně co nejméně omezovalo všechny daňové poplatníky i správce daně, tedy Finanční úrad. Tzn. minimalizaci nákladů souvisejících s výběrem daní. Správu daní, respektive finanční úřady, respondenti shledali za spíše kvalitní. Důvodem je snaha o celkové zlepšení v této oblasti, kde ze strany vlády je vidět tendence ke spolupráci, a to $\mathrm{v}$ rámci aktivního př́stupu daňové správy $\mathrm{k}$ veřejnosti. Daňovou soustavu zhodnotili daňový poplatníci z OPF za neadekvátní vzhledem $\mathrm{k}$ celkové životní úrovni. To znamená, že ekonomická realita, se kterou se běžně setkávají, neodpovídá úrovni vybraným daním. Jeden z nejdůležitějších vlivů daní, považují respondenti vliv daní na podnikání v ČR. S ohledem na předešlé výsledky šetření ukazující na nespokojenosti výši sazby daně, můžeme vysledovat demotivující pohled respondentů na podnikání v ČR. Dalším demotivujícím prvkem je vyjádřený názor ukazující na výhodnější postavení zahraničních firem, zvýhodněnými daňovými úlevami, před firmami českými. Dle názoru tázaných respondentů je nezbytný motivační krok pro podnikání v ČR, přiblížení daňových úlev pro české firmy.

\section{Literatura:}

[1] BOIY, T. Late Achaemenid and Hellenistic Babylon. 1st ed. Leuven: Peeters Publishers \& Department of Oriental Studies, Belgium, 2004. 385 p. ISBN 90-4291449-1.

[2] COSGEL, M. M. and MICELI, T. J., Economics Working Papers. Paper 200748. Tax Collection in History, 2007. [online] [cit. 2012-03-08]. Available on: http://digitalcommons.uconn.eduecon_wpapers/200748

[3] JANOUŠKOVÁ, J. Daně a daňová politika. 1. vyd. Karviná: SU OPF, 2011, 135 s. ISBN 978-80-7248-653-3.

[4] KERRIGAN, M. The Ancients in Their Own Words. Fall River Press, Amber Books Ltd, c 2009, 1st ed. 224 p. ISBN 978-1435107243.

[5] KUBÁTOVÁ, K. Daňová teorie a politika. 1. vyd. Praha: Eurolex Bohemia, 2000, 225 s. ISBN 80-902752-2-2.

[6] KUBÍČEK, J. a kol. Hospodářská politika, Plzeň: Vydavatelství a nakladatelství Aleš Čeněk. 2006, 302 s. ISBN 80-86898-99-7.

[7] OPPENHEIM, A. LEO. Ancient Mesopotamia: Portrait of a Dead Civilization. Revised ed. Chicago and London: University Of Chicago Press, 1977. 445 p. ISBN 978-0226631875.

[8] OSBORNE, R. The History Written on the Classical Greek Body. 1st ed. New York: Cambridge University Press, 2011. 276 p. ISBN 978-0521176705.

[9] SPUNAR, P. a kol. Kultura středověku. 2. pozměněné a doplněné vyd. Praha: Academia, 1995. 226 s. ISBN 80-200-0547-1.

[10] ŠIROKÝ, J. A KOL. Tvoříme a publikujeme odborné texty nejen pro ekonomy a manažery. Brno: Computer Press, 2011. 208 s. ISBN 978-80-251-3510-5.

[11] VANČUROVÁ, A., LÁCHOVÁ, L. Daňový systém 2010 ČR. Praha: VOX. 355 s. ISBN 978-80-86324-86-9.

[12] VÍTEK, L. Daňová politika České republiky: historický vývoj, současnost a perspektivy zdanění na území ČR $\mathrm{s}$ ohledem na integraci českého hospodářství do světového ekonomického společenství. Praha: Národohospodářský ústav Josefa Hlávky, 2001. ISBN 80-238-8182-5.

[13] Daňová soustava ČR [online]. [cit. 2012-02-02]. Vlastní zpracování na základě informací získaných z WWW: <http://www.mfcr.cz/cps/ rde/xchg/ $\mathrm{mfcr} / \mathrm{xsl} /$ zakony.html>. 
JEL E20, E60, H20, H21

\section{Ing. Monika Wiesner}

Studentka doktorského studia Katedra účetnictví

Obchodně podnikatelská fakulta v Karviné

Slezská univerzita v Opavě

Univerzitní náměstí 1934/3, 73340 Karviná

Tel.: +420 596398632

pavlikova@opf.slu.cz

\section{Ing. Eva Mauritzová}

Studentka doktorského studia Katedra účetnictví Obchodně podnikatelská fakulta v Karviné Slezská univerzita v Opavě

Univerzitní náměstí 1934/3, 73340 Karviná

Tel.: +420 596398632

mauritzova@opf.slu.cz 